\title{
PENGEMBANGAN KECAKAPAN HIDUP WARGA BINAAN DI DALAM \\ LEMBAGA PEMASYARAKATAN MELALUI BIMBINGAN KERJA SEBAGAI BENTUK PEMENUHAN HAK ASASI MANUSIA (Development Of Proficiency Of The Life Of Development Citizens In Corruption Institutions Through Work Guidance As A Form Of Fulfilling
}

\section{Human Rights)}

\author{
Hendra Ekaputra; Faisal Santiago \\ Program Doktor Ilmu Hukum, Universitas Borobudur \\ hendraeputra@gmail.com
}

\begin{abstract}
Correctional institutions have the function of guiding to assist residents to prevent criminal acts, and resolving conflicts, as well as improving assisted residents so that they re-integrate with the community. Correctional Institutions need to implement a correctional system that is oriented towards guidance. In human rights, fostering the personality and independence of the assisted citizens is an effort to fulfil human rights, namely the right to obtain education and opportunities for personal development. In this study, it discusses the study of questions (1) how do the law and regulation governing the implementation of job training and skills for prisoners; (2) how the law and regulation can provide legal guarantees for the implementation of job training and skills of assisted citizens to fulfil human rights. This type of research is juridical empirical, namely research on the study of applicable legal provisions and what happens in reality to society. From the existing regulations, The correctional institution guidance aim is to towards fostering assisted citizens to improve their personality. So that they do not repeat criminal acts that they have committed, and can continue and rebuild their lives to gain prosperity, and return to live side by side with the community
\end{abstract}

Keywords : correctional institutions; work guidance; human rights.

\begin{abstract}
ABSTRAK
Lembaga Pemasyarakatan memiliki tugas dan fungsi melakukan pembinaan terhadap warga binaan yang bertujuan mencegah terjadinya tindak pidana, memulihkan keseimbangan, dan menyelesaikan konflik, serta memperbaiki warga binaan agar nantinya mampu berbaur dengan masyarakat. Lembaga Pemasyarakatan perlu melaksanakan sistem pemasyarakatan yang berorientasi terhadap pembinaan. Dalam hukum hak asasi manusia, pembinaan kepribadian dan kemandirian warga binaan pemasyarakatan adalah upaya pemenuhan hak asasi manusia yakni hak untuk memperoleh pendidikan dan kesempatan pengembangan diri. Pada penelitian ini membahas kajian terhadap pertanyaan (1) bagaimana peraturan perundangan yang mengatur tentang penyelenggaraan pelatihan kerja dan keterampilan bagi warga binaan pemasyarakatan; (2) bagaimana peraturan perundangan dapat memberikan jaminan hukum terhadap pelaksanaan pelatihan kerja dan keterampilan warga binaan pemasyarakatan sebagai bentuk pemenuhan hak asasi manusia. Jenis penelitian ini adalah yuridis empiris, yaitu penelitian terhadap kajian ketentuan hukum yang berlaku serta apa yang terjadi dalam kenyataanya pada masyarakat. perlu diketahui bahwa dari perautran-peraturan yang ada, pembinaan yang dilakukan oleh lembaga pemasyarakatan berorientasi terhadap pembinaan warga binaan guna memperbaiki pribadinya sehingga tidak mengulangi lagi tindak pidana yang pernah dilakukannnya dan dapat melanjutkan hidup serta membangun hidupnya kembali untuk memperoleh hidup yang sejahtera dan dapat hidup berdampingan dengan masyarakat lainnya.
\end{abstract}

Kata Kunci: Lembaga Pemasyarakatan; bimbingan kerja; Hak Asasi Manusia 


\section{PENDAHULUAN}

Pada mulanya di Indonesia, tempat pelaksanaan hukuman bagi narapidana ataupun tahanan disebut sebagai Penjara. Dalam perkembangan waktu istilah "Penjara" diubah menjadi Lembaga Pemsayarakatan. Perubahan istilah ini berangkat dari tugas dan fungsi penjara saat itu yang tidak hanya sebagai lembaga pelaksana hukuman tetapi juga pemasyarakatan yakni pembinaan narapidana dan tahanan.

Konsep pemasyarakatan pertama kali digagas oleh Menteri Kehakiman Republik Indonesia, Sahardjo pada tahun 1962 yang menyatakan bahwa tugas jawatan kepenjaraan bukan hanya melaksanakan hukuman, melainkan juga tugas yang jauh lebih berat yakni mengembalikan orang-orang yang dijatuhi pidana ke dalam masyarakat. ${ }^{1}$ Pada Tahun 1995, lahirlah Undang-Undang Negara Republik Indonesia Nomor 12 Tahun 1995 tentang Lembaga Pemasyarakatan (UndangUndang Pemasyarakatan). Berdasarkan undangundang ini, "Penjara" dirubah namanya menjadi "Lembaga Pemasyarakatan" yang disingkat LAPAS atau sering juga disebut LP yang pelaksanaannya menggunakan sistem pemasyarakatan. $^{2}$

Undang-Undang Pemasyarakatan juga mengubah istilah atau nama bagi Penghuni Lembaga Pemasyarakatan yang disebut sebagai Warga Binaan Pemasyarakatan (WBP) $)^{3}$ yakni narapidana yang merupakan orang-orang yang sudah divonis oleh pengadilan dan telah berkekuatan hukum tetap atau juga tahanan yakni orang yang masih dalam proses peradilan. Sedangkan Pegawai negeri sipil yang bertugas melakukan pembinaan narapidana dan tahanan di lembaga pemasyarakatan disebut sebagai Petugas Pemasyarakatan.

Berdasarkan Pasal $1^{4}$ Undang-Undang Pemasyarakatan, Lembaga Pemasyarakatan pada pokoknya memiliki tugas dan fungsi untuk melakukan pembinaan terhadap warga binaan yang bertujuan untuk mencegah kembali terjadinya tindak pidana, memulihkan

1 Muhyar Nugraha, "Pola Pembinaan Narapidana Di Lapas Paledang Bogor Sebagai Pelaksanaan Sistem Pemasyarakatan," Jurnal Yustisi 4, no. 2 (2017): 15-27.

2 UU Nomor 12 Tahun 1995 Tentang Pemasyarakatan, n.d., www.bphn.go.id.

3 Ibid.

4 Ibid. keseimbangan, dan meyelesaikan konflik, serta memperbaiki warga binaan dan menyiapkan warga binaan agar nantinya mampu berbaur secara sehat dengan masyarakat. Kegiatan pembinaan terhadap warga binaan pemasyarakatan di Lembaga Pemasyarakatan dilakukaan dengan 2 jenis pembinaan, yaitu pembinaan kepribadian dan kemandirian ${ }^{5}$ Salah satu kegiatan pembinaan kemandirian bagi warga binaaan pemasyarakatan dilakukan melalui pendidikan dan pengembangan kecakapan hidup yang salah satunya melalui pembinaan keterampilan kerajinan.

Peranan Lembaga Pemasyarakatan dalam melaksanakan pembinaan keterampilan kerajinan tersebut adalah dengan memberi bimbingan berupa pemberian materi tentang keterampilan kerajinan, menyediakan saranaprasarana yang dibutuhkan, serta mendampingi narapidana secara langsung hingga warga binaan tersebut mampu membuat kerajinan dengan baik. Dengan demikian, warga binaan harus dibekali keterampilan sesuai dengan kemampuan dan pengertian mengenai normanorma kehidupan serta melibatkan mereka dalam kegiatan-kegiatan sosial yang dapat menumbuhkan percaya diri dalam kehidupan bermasyarakat, agar warga binaan sanggup hidup mandiri dan mampu bersaing dengan masyarakat tanpa melakukan kejahatan lagi. ${ }^{6}$

Dalam perspektif hukum hak asasi manusia, pembinaan kepribadian dan kemandirian warga binaan pemasyarakatan dapat disebut sebagai upaya implementasi pemenuhan hak asasi manusia yakni hak untuk memperoleh pendidikan dan kesempatan pengembangan diri. Karena bagi setiap warga binaan pemasyarakatan, hanya hak atas kemerdekaannya saja yang dirampas dan/atau dikurangi berdasarkan hukum tetapi hak-hak untuk hidup dan mengembangkan diri adalah hak fundamental yang tak boleh dikurangi dan harus dipenuhi oleh negara. Dengan demikian perlu dilihat apakah pelaksanaan pembinaan bagi warga binaan pemasyarakatan di dalam Lembaga Pemasyarakatan yang telah dilakukan berdasarkan peraturan perundang-undangan

5 Keputusan Menteri Kehakiman Republik Indonesia No: M. 02-PK.04.10 Tahun 1990, 1990.

6 Nurini dkk Aprilianda, Model Pembinaan Anak Berbasis Pendidikan Layak Anak Dalam Sistem Pemasyarakatan, Laporan Akhir Pengkajian Hukum, 2014. 
yang berlaku telah sejalan dengan hukum hak asasi manusia terkait dengan hak untuk mendapat pendidikan untuk mengembangan diri.

Tetapi dalam pelaksaannya program pelatihan kerja dan keterampilan bagi warga binaan pemasyarakatan yang diselakukan oleh lembaga pemasyarakatan kerap menghadapi permasalahan dan kendala yang membuat pelatihan kerja dan keterampilan bagi warga binaan pemasyarakatan seperti tidak efektif. Kendala-kendala ini dapat terjadi mungkin karena regulasi, fasilitas dan kesempatan, pembinaan yang tidak komprehensif, fasilitas dan dukungan pembiayaan oleh negara serta faktor ketertarikan warga binaan terhadap kegiatan tersebut.

Berdasarkan uraian tersebut, perlu dilakukan pembahasan dan/atau kajian terhadap pertanyaan Pertama, bagaimana peraturan perundang-undangan mengatur tentang penyelenggaraan pelatihan kerja dan keterampilan bagi warga binaan pemasyarakatan, dan Kedua, bagaimana peraturan perundang-undangan dapat memberikan jaminan hukum terhadap pelaksanaan pelatihan kerja dan keterampilan bagi warga binaan pemasyarakatan sebagai bentuk pemenuhan hak asasi manusia agar warga binaaan dapat kembali hidup berbaur secara sehat dengan masyarakat paska menjalani hukuman dan tidak lagi mengulangi perbuatannya.

Lembaga Pemasyarakatan atau LAPAS adalah tempat untuk melaksankan pembinaan Narapidana dan anak didik pemasyarakatan ${ }^{7}$ yang merupakan Unit Pelaksana Teknis di bawah Direktorat Jenderal Pemasyarakatan Kementerian Hukum dan Hak Asasi Manusia. Tugas dan Fungsi dari Lembaga Pemasyarakatan adalah melaksanakan pembinaan terhadap narapidana. Pembinaan narapidana didasarkan pada sistem pemasyarakatan. Sistem pemasyarakatan diselenggarakan dalam rangka membentuk warga binaan agar menjadi manusia seutuhnya, menyadari kesalahan, memperbaiki diri dan tidak mengulangi tindak pidana sehingga dapat

\footnotetext{
7 UU Nomor 12 Tahun 1995 Tentang Pemasyarakatan.

8 Ibid.

9 Dicky Febrian Ceswara, "Manusia Dalam Sila Pancasila," Lex Scientia Law Review 2, no. 2 (2018): 227-241.
}

diterima kembali oleh lingkungan masyarakat, dapat aktif berperan dalam pembangunan dan dapat hidup secara wajar sebagai warga Negara yang baik dan bertanggungjawab. ${ }^{8}$

Walaupun warga binaan pemasyarakatan telah kehilangan kemerdekaannya, tapi ada hakhak asasi sebagai manusia yang tetap harus dilindungi dalam sistem pemasyarakatan Indonesia. Hak Asasi Manusia (HAM) adalah hak-hak dasar yang dimiliki setiap pribadi manusia yang tanpa hak itu kita mustahil hidup sebagai manusia? ${ }^{9}$. Dalam hukum hak asasi manusia, setiap orang berhak untuk mendapatkan penghormatan, perlindungan dan pemenuhan hak asasi manusia dari negara yang dilakukan tanpa diskriminasi. Oleh karenanya warga binaan pemasyarakatan yang sedang menjalani hukuman didalam lembaga pemasyarakatan juga harus mendapatkan jaminan dari negera untuk terpenuhi hakhaknya sebagai manusia.

Berkaitan dengan fungsi lembaga pemasyarakatan yang salah satunya adalah melakukan pembinaan terhadap warga binaan pemasyarakatan agar nantinya setelah bebas mampu berbaur secara sehat dengan masyarakat. Lembaga Pemasyarakatan melakukan program pembinaan mandiri yakni pendidikan dan pengembangan kecakapan hidup yang diantaranya adalah program pelatihan kerja dan keterampilan yang dilaksanakan sebagai bagian dari upaya pemenuhan hak-hak asasi warga binaan pemasyarakatan yakni hak untuk hidup, ${ }^{10}$ hak untuk mengembangkan diri, dan hak atas kesejahteraan. agar warga binaan pemasyarakatan dapat melanjutkan hidup dan membangun hidupnya kembali untuk memperoleh hidup yang sejahtera dan hidup berdampingan dengan masyarakat lainnya.

Pembinaan berasal dari kata "bina" yang berarti sama dengan "bangun", jadi pembinaan dapat diartikan sebagai melakukan usaha-usaha untuk merubah sesuatu sehingga menjadi baru yang memiliki nilai-nilai yang tinggi atau untuk membuat sesuatu menjadi lebih sesuai atau cocok dengan kebutuhan dan menjadi lebih baik dan lebih bermanfaat. ${ }^{11}$ Pembinaan juga dapat

\footnotetext{
10 UU Nomor 12 Tahun 1995 Tentang Pemasyarakatan.

11 Pramudji, Kerjasama Antar Daerah Dalam Rangka Pembinaan Wilayah: Suatu Tinjauan Dari Segi Administrasi Negara: Sutau Tinjauan Dari Segi Administrasi Negara, (Jakarta: Bina Aksara, 1985), Hal.7
} 
diartikan sebagai suatu usaha yang dilakukan dengan sadar, berencana, teratur, dan terarah untuk meningkatkan sikap dan keterampilan anak didik dengan tindakan-tindakan, pengarahan, pembimbingan, pengembangan dan simulasi dan pengawasan untuk mencapai tujuan. ${ }^{12}$

Menurut Murray (1983), bimbingan kerja atau karir dapat dikatakan sebagai suatu rentangan aktivitas pekerjaan yang saling berhubungan; dalam hal ini seseorang memajukan kehidupannya dengan melibatkan berbagai perilaku, kemampuan, sikap, kebutuhan, aspirasi, dan cita-cita sebagai satu rentang hidupnya sendiri. ${ }^{13}$ Pengertian Life Skill atau biasa disebut sebagai kecakapan hidup jika dilihat dari segi bahasa berasal dari dua kata yaitu life dan skill. Life berarti hidup, sedangkan skill adalah kecakapan, kepandaian, ketrampilan. Sehingga life skill secara bahasa dapat diartikan sebagai kecakapan, kepandaian, keterampilan hidup. Umumnya dalam penggunaan sehari-hari orang menyebut life skill dengan istilah kecakapan hidup. ${ }^{14}$ Kecakapan Hidup (Life Skill) tidak semata-mata diartikan memiliki keterampilan tertentu (vocational job) saja, namun ia harus memiliki kemampuan dasar pendukungnya secara fungsional seperti mambaca, menghitung, merumuskan, dan memecahkan masalah, mengelolah sumber daya, bekerja dalam tim, terus belajar ditempat kerja mempergunakan teknologi. menurut Anwar Program pendidikan life skill adalah pendidikan yang dapat memberikan bekal ketrampilan yang praktis terpakai, terkait dengan kebutuhan pasar kerja, peluang usaha dan potensi ekonomi atau industri yang ada di masyarakat. ${ }^{15}$

\section{METODE PENELITIAN}

Penelitian ini dilakukan dengan menggunakan metode penelitian yuridis empiris atau biasa disebut dengan penelitian lapangan,

12 FItria (Universitas Raden Intan/Lampung) Ridhowati, "Manajemen Pembinaan Mental Spiritual Terhadap Narapidana Pada Lembaga Permasyarakatan Way Huwi Kabupaten Lampung Selatan," 2018.

13 Pratama and Fauzi, "Efektivitas Program Bimbingan Kerja Dalam Mengembangkan Life Skill Warga Binaan Penjara," Keguruan dan Ilmu Pendidikan 2, no. 2 (2018): 126-140.

14 Eko Eddya Supriyanto, "Kontribusi Pendidikan Pesantren Bagi Pendidikan Karakter Di yaitu penelitian terhadap kajian ketentuan hukum yang berlaku serta apa yang terjadi dalam kenyataanya pada masyarakat. Pada dasarnya penelitian yuridis empiris ini merupakan penelitian hukum yang berkaitan dengan implementasi ketentuan hukum normatif secara in action dalam peristiwa hukum tertentu yang terjadi dalam masyarakat. ${ }^{16}$ Model penelitian ini dilakukan terhadap keadaan sebenarnya atau keadaan nyata yang terjadi pada masyarakat dengan maksud untuk mengetahui dan menemukan fakta-fakta dan data yang dibutuhkan, setelah data terkumpul kemudian dilakukan identifikasi masalah hingga pada penyelesaian masalah. Penelitian evaluasi terhadap hukum positif ini dilakukan dengan cara mengevaluasi segi kesesuaian antara satu kaidah hukum dengan kaidah hukum lainnya atau dengan asas hukum yang diakui dalam praktik hukum yang ada, yang dilakukan dengan cara meneliti bahan pustaka atau data sekunder. ${ }^{17}$

Secara metodologis, penelitian menggunakan pendekatan pemecahan masalah dengan pendekatan hukum yang diposisikan sebagai norma atau das sollen, karena dalam melakukan pembahasan masalah dalam penelitian ini menggunakan bahan-bahan hukum (baik hukum tertulis maupun hukum tidak tertulis yang terdiri atas bahan hukum primer, sekunder maupun tersier). Penelitian ini bergerak pada dua level, yakni konseptual dan analitis. Pada level pertama konseptualisasi hukum dipandang sebagai sebuah proses komunikasi. Pada sisi ini regulasi atau peraturan perundang-undangan diposisikan sebagai proses interaksi serta perebutan aksi (meaning) antar aktor yang terlibat di dalamnya. ${ }^{18}$ Pendekatan ini umumnya merupakan suatu ilmu yang normatif, karena dalam penelitian hukum kecenderungannya bagian dari humaniora (Humanities atau Geistes-wissenschaften). Kejadian tersebut karena adanya pengaruh dari aliran empirisme dan positivisme dari ilmu-ilmu

Indonesia," Jurnal Pendidikan NUsantara 1, no. 1 (2020): 13-26.

15 Pratama and Fauzi, "Efektivitas Program Bimbingan Kerja Dalam Mengembangkan Life Skill Warga Binaan Penjara."

16 Ahmad Zuhdi, "Perkembangan Metodologi Penelitian Hukum," Jurnal Hukum dan Peradilan, 1, no. 2 (2012): 189-206.

17 Ibid.

18 Pierre Bourdieu, "The Force of Law : Toward a Sociology of the Juridical Field The Force of Law : Toward a Sociology Of' 38, no. 5 (1987). 
sosial, sehingga terlihat adanya kecenderungan untuk melihat hukum sebagai suatu gejala sosial (social feit) dari pada sebagai suatu kumpulan norma-norma yang berlaku dalam interaksi antara manusia didalam kehidupan bernegara. ${ }^{19}$

Dalam penelitian ini, data pustaka digunakan sebagai data utama, yakni bahan hukum primer berupa norma atau aturan dasar dan peraturan perundang-undangan. Dan juga menggunakan bahan hukum sekunder seperti hasil penelitian serta pendapat para akademisi dan pakar hukum. Penelitian ini dihadapkan pada posisi hukum yang menelaah kehidupan nyata dengan konteks sumber-sumber hukum sebagai sumber primer dan sekunder sehingga dapat menemukan sisi humanisme pada pemberian pelatihan kerja kepada warga binaan.

\section{PEMBAHASAN}

A. Peraturan Perundang-Undangan Yang Mengatur Tentang Penyelenggaraan Pelatihan Kerja Dan Keterampilan Bagi Warga Binaan Pemasyarakatan

Negara Kesatuan Republik Indonesia adalah negara hukum ${ }^{20}$ sehingga semua aspek kehidupan dalam bermasyarakat, berbangsa, bernengara dan pemerintahan harus selalu berdasarkan atas hukum. Negara Kesatuan Republik Indonesia oleh karenanya wajib menjunjung tinggi hukum dan harus memberikan rasa keadilan bagi seluruh masyarakat terutama yang membutuhkan perlindungan hukum dan dijamin oleh negara.

Prinsip keadilan ini memberikan konsep bahwa setiap warga negara sama di mata hukum ini menyatakan salah satu kaidah hukum. Asas persamaan kedudukan didalam hukum ini sangat penting ditegakkan terutama dalam kehidupan bermasyarakat.

Pelaksanaan pidana penjara dengan sistem pemasyarakatan di Indonesia saat ini mengacu kepada Undang-Undang Nomor 12 Tahun 1995 Tentang Pemasyarakatan. Didalam Penjelasan Umum UndangUndang Pemasyarakatan yang merupakan dasar hukum perubahan ide secara yuridis dan filosofis dari sistem kepenjaraan

19 Zulfi Diane Zaini, "Implementasi Pendekatan Yuridis Normatif Dan Pendekatan Normatif Sosiologis Dalam Penelitian Ilmu Hukum," Pranata Hukum, 2011. menjadi sistem pemasyarakatan, mengatur tentang pelaksanaan sistem pemasyarakatan di Indonesia yang dinyatakan bahwa: ${ }^{21}$

1) Bagi Negara Indonesia yang berdasarkan Pancasila, pemikiranpemikiran baru mengenai fungsi pemidanaan yang tidak lagi sekedar pemenjaraan juga merupakan suatu usaha rehabilitasi dan reintegrasi sosial. Warga Binaan Pemasyarakatan telah melahirkan suatu sistem pembinaan yang sejak lebih dari 30 (tiga puluh) tahun yang dikenal dan dinamakan dengan Sistem Pemasyarakatan.

2) Sistem pemenjaraan yang sangat menekankan pada unsur balas dendam dan penjeraan yang disertai dengan lembaga "rumah penjara" secara berangsur-angsur dipandang sebagai suatu sistem dan sarana yang tidak sejalan dengan konsep rehabilitasi dan reintegrasi sosial agar narapidana menyadari kesalahannya, tidak lagi berkehendak untuk melakukan tindak pidana dan kembali menjadi warga masyarakat yang bertanggung jawab bagi diri, keluarga, dan lingkungan.

Pada prinsipnya Undang-Undang Pemasyarakatan menekankan perubahan paradigma dan konseptual dari sistem pemenjaraan yang menekenkan unsur balas dendam yang tidak sesuai lagi dengan tuntuan jaman berubah menjadi konsep pemasyarakatan yang menekenkan upaya rehabilitasi dan pembinaan agar warga binaan pemasyarakatan dapat melanjutkan hidup dan membangun hidupnya kembali untuk memperoleh hidup yang sejahtera dan hidup berdampingan dengan masyarakat lainnya.

Dalam pelaksanaan pembinaan warga binaan pemasyarakatan, terdapat beberapa regulasi yang mengatur secara khusus berkaitan dengan kegiatan kerja narapidana yaitu:

20 Undang Undang Dasar Negara Republik Indonesia Tahun 1945, Pasal 1 angka (3)

21 Dwidja Priyanto, Sistem Pelaksanaan Pidana Penjara di Indonesia, (Bandung: Refika Aditama, 2006), Hal. 102 
1. Undang-Undang Nomor 12 Tahun 1995 tentang Pemasyarakatan; di dalam konsideran undang-undang ini disebutkan bahwa pada hakikatnya Warga Binaan Pemasyarakatan sebagai insan dan sumber daya manusia harus diperlakukan dengan baik dan manusiawi dalam satu sistem pembinaan yang terpadu.

2. Peraturan Pemerintah Nomor 31 Tahun 1999 tentang Pembinaan dan Pembimbingan Warga Binaan Pemasyarakatan; Pasal 3 Peraturan Pemerintah ini menegaskan bahwa beberapa bentuk pembinaan dan pembimbingan kepribadian dan kemandirian bagi narapidana adalah keterampilan kerja, latihan kerja dan produksi.

3. Peraturan Menteri Hukum dan Hak Asasi Manusia Republik Indonesia Nomor M.HH-05.OT.01.01 Tahun 2010 Tanggal 30 Desember 2010 Tentang Organisasi dan Tata Kerja Kementerian Hukum dan Hak Asasi Manusia Republik Indonesia disebutkan bahwa Bimbingan Kemandirian melaksanakan penyiapan kebijakan, pembinaan dan pelaksanaan teknis di bidang:

1) Bimbingan Latihan Keterampilan atau Kegiatan Pelatihan.

2) Kegiatan Kerja Industri dan Jasa.

3) Kegiatan Kerja Pertanian dan Perkebunan; dan

4) Kegiatan Kerja Perikanan dan Peternakan.

Terkait Pembinaan bagi warga binaan pemasyarakatan, diatur oleh Surat Edaran Menteri Kehakiman Republik Indonesia Tanggal 31 Mei 1989 Nomor: M.01-PK.03.01 Tahun 1989 Tentang Tata Laksana Pengelolaan dan Pengadministrasian Kegiatan Bengkel Kerja yang kemudian diatur secara tekhnis oleh Petunjuk Pelaksanaan Direktur Jenderal Pemasyarakatan Nomor: E-04.PK.03.01 Tahun 1990 tentang Pelaksanaan Surat Edaran Menteri Kehakiman Republik Indonesia Tanggal 31 Mei 1989 Nomor: M.01-PK.03.01 Tahun 1989 Tentang Tata Laksana Pengelolaan dan

22 Peraturan Menteri Hukum Dan Hak Asasi Manusia Republik Indonesia Nomor 35 Tahun
Pengadministrasian Kegiatan Bengkel Kerja, yang pada pokoknya mengatur tentang:

1) Pengertian bengkel kerja (bengker) sebagai kegiatan produktif.

2) Penganekaragaman dan pengembangan bengkel kerja.

3) Sistem keuangan.

4) Jenis kegiatan bengkel kerja.

5) Pembuatan laporan kegiatan bengkel kerja.

Dalam perjalanannya, untuk memperkuat program pembinaan melalui pelatihan kerja dan keterampilan bagi warga binaan pemasyarakatan, Kementerian Hukum dan Hak Asasi Manusia Republik Indonesia mengeluarkan peraturan Peraturan Menteri Hukum Dan Hak Asasi Manusia Republik Indonesia Nomor 35 Tahun 2018 Tentang Revitalisasi Penyelenggaraan Pemasyarakatan. Secara spesifik mengaskan bahwa peraturan ini dikeluarkan untuk melakukan optimalisasi dan penguatan penyelenggaraan pemasyarakatan guna mencapai tujuan pidana yaitu melakukan pembinaan agar narapidana tidak mengulang perbuatan hukum dan mendidik mereka agar memiliki keterampilan sosial dan berwirausaha yang didukung dengan situasi aman dan kondusif, perlu dilakukan penataan dan pembaharuan manajemen pemasyarakatan. ${ }^{22}$ Dimana revitalisasi penyelenggaraan pemasyarakatan dilakukan bertujuan untuk: ${ }^{23}$

a. Meningkatkan pelaksanaan tugas dan fungsi pemasyarakatan.

b. Meningkatkan objektifitas penilaian perubahan perilaku Tahanan, Narapidana dan Klien sebagai pedoman dalam pelaksanaan Pelayanan, Pembinaan dan Pembimbingan.

c. Meningkatkan peran Pembimbing Kemasyarakatan.

d. Meningkatkan penyelenggaraan Pengamanan pada Lapas dan Rutan; dan

e. Meningkatkan perlindungan hak kepemilikan atas barang bukti hasil tindak pidana.
2018 Tentang Revitalisasi Penyeleyenggaraan Pemasyarakatan, 2018.

23 Ibid, Pasal 2 
Didalam peraturan mengenai revitalisasi penyelenggaraan pemasayarakatan diatur juga secara spesifik terkait dengan pembinaan bagi warga binaan pemasyarakatan yakni:

1) Pemberian program Pembinaan Narapidana dan waktu penilaian perubahan sikap serta perilaku Narapidana pada Lapas Medium Security sebagaimana dimaksud dalam Pasal 18 dilakukan berdasarkan hasil Litmas dan rekomendasi sidang tim pengamat pemasyarakatan.

2) Program Pembinaan Narapidana sebagaimana dimaksud pada Ayat (1) meliputi:
a. pendidikan dan pelatihan keterampilan tingkat pemula.
b. pendidikan dan pelatihan c. pendidikan dan pelati

3) Setiap Narapidana yang telah mengikuti pendidikan dan pelatihan keterampilan tingkat mahir sebagaimana dimaksud pada Ayat (2) huruf c diberikan sertifikat kemampuan dan keahlian oleh Kepala Lapas.

4) Penyelenggaraan program Pembinaan Narapidana sebagaimana dimaksud pada Ayat (2) dilaksanakan dengan metode pelatihan dan pendidikan.

5) Pelaksanaan program Pembinaan Narapidana sebagaimana dimaksud pada Ayat (2) dapat dilakukan di luar Lapas melalui program asimilasi dalam bentuk pemagangan.

6) Ketentuan mengenai petunjuk teknis pelaksanaan program Pembinaan Narapidana sebagaimana dimaksud pada Ayat (2) ditetapkan oleh Direktur Jenderal.

Dari penjelasan perarturan perundangundangan yang ada diatas, dapat diketahui bahwa, sistem pemasyarakatan yang dijalankan oleh Lembaga Pemasyarakatan memang berorientasi terhadap pembinaan warga binaan pemasyarakatan agar warga binaan dapat memperbaiki pribadinya sehingga tidak mengulangi lagi tindak pidana yang pernah dilakukannnya dan

24 Z. Afrilya and N. Widyarini, "Efektivitas Intervensi Pelatihan Goal Setting Pada Warga Binaan Sosial (Wbs) Di Panti Sosial Bina Karya dapat melanjutkan hidup serta membangun hidupnya kembali untuk memperoleh hidup yang sejahtera dan dapat hidup berdampingan dengan masyarakat lainnya.

\section{B. Manajemen Pelatihan Kerja dan Keterampilan Bagi Warga Binaan}

1. Proses Perencanaan Pelatihan Keterampilan Bagi Narapidana

Hal penting dalam menjalankan tugas yakni memanajen dulu. Perencanaan berkaitan dengan, penyusunan tujuan dan rangkaian kegiatan untuk mencapai tujuan pemasyarakatan. Adapun tujuan pelatihan keterampilan bagi narapidana adalah menambah pengalaman tentang dunia kerja jika, menambah Ilmu melalui pelatihan bengkel kerja, merubah karakter narapidana dan membangun kemandirian narapidana paska narapidana.

Setelah itu langkah selanjutnya adalah penentuan instruktur pelatih dalam pelatihan. Dalam penentuan instruktur pelatihan mengutamakan pihak SDM dari dalam yang menjadi instruktur guna menghemat biaya, jika SDM dari dalam RUTAN tidak bisa dan kurang berpengalaman baru dicarikan instruktur dari pihak ketiga bentuk kerjasama ataupun bayaran. Seperti pelatihan pembuatan kue kering yang dilatih oleh Pihak Ketiga. Dalam hal ini pihak ketiga mengajarkan pembuatan kue sus. Memanfaatkan SDM dari dalam merupakan bentuk efisisensi dan tidak membutuhkan uang banyak. Selain itu setiap program bengkel kerja ada tamping atau pekerja dibidang loundri, salon potong rambut, home industry roti Arjuna, perkayuan dan las, cuci motor, pertanian, dan menjahit ini akan diberlakukan sebagi pelatih. ${ }^{24}$

Proses selanjutnya pendaftaran dan perekrutan peserta pelatihan diumumkan melalui papan pengumuman dan mendatangi tiap-tiap blok ataupun tiap kamar. Peserta akan diseleksi kesungguhannya untuk mengikuti pelatihan tersebut. Meskipun cara pendaftarannya sistem peminatan dan bakat peserta. Karena setiap peserta

(Psbk) Pangudi Luhur Bekasi," Jurnal Ilmiah Psikologi Gunadarma 8, no. 2 (2015): 178774. 
diseleksi sesuai masa tahanan dan keseriusannya. Untuk mengenai seleksi peserta hal ini juga harus direncanakan terlebih dahulu. Peserta pelatihan bisa mengikuti pembimbingan dan pelatihan yang ada dibengkel kerja jika sudah menjalani masa tahanan selama $1 / 2$ masa tahanan atau minimal 6 bulan masa tahanan. Setelah itu jika mereka minat bisa mendaftarkan diri dibengkel kerja melalui BIMKEG ${ }^{25}$. Sistem perekrutan ini akan meminimalisir pengeluaran anggaran.

2. Materi, Metode yang digunakan dalam Pelatihan

Untuk materi pelatihan keterampilan menggunakan materi yang ada dibengkel kerja yang ada. Pada tahun 2019 pihak BIMKEG mengajukan proposal kerjasama dalam hal pelatihan. Kerjasama dalam bentuk instruktur pelatihan. Dalam hal ini narapidana diberi materi mengenai perkayuan dan las. BIMKEG juga meminta bantuan hal cuci motor meminta bantuan alat cuci motor. Dengan sekali pelatihan selanjutnya yang meneruskan pihak RUTAN. Dengan sistem hasil dari pelatihan tersebut siapa peserta yang unggul memiliki SDM dan keterampilan yang bisa dibuktikan dengan teori dan praktiknya serta sungguh-sungguh dia mau bekerja. Jika hasilnya bagus peserta atau narapidana yang ikut pelatihan tersebut direkrut dan diperkerjakan sesuai dengan bidangnya. Sampai mereka puas dengan pekerjaannya tersebut dan bisa mengajarkan ilmunya pada narapidana yang minat. Dan bisa dievaluasi jika mereka sudah ahli dan bisa mengajarkan orang yang minat untuk menjadi tamping.

Metode yang digunakan dalam pelatihan tersebut harus sesuai dengan bidangnya. Dalam bidang perkayuan pelatih menggunakan metode penyampaian teori dan dalam lapangan menggunakan teori dan praktik mensertakan alat-alat perkayuan. Dalam bidang pembutan roti pelatih

25 Khasanah Khuswatun, "Implementasi Program Bimbingan Kerja Dalam Pemberdayaan menggunakan metode langsung praktik mensertakan alat-alatnya seperti mesin pengaduk adonan, mesin oven, mesin penggorengan, peralatan dapur dan bahan-bahan pembuatan roti.

$\mathrm{Hal}$ ini menunjukkan bahwa menggunakan alat dan fasilitas yang ada merupakan hal yang efektif dan efisien tidak membutuhkan biaya dan persiapan yang banyak.

3. Pelaksanaan Pelatihan

Dalam pelaksanaan pelatihan disini pelatih praktik langsung dan dilihat oleh peserta. Jika peserta sudah dirasa bisa baru peserta mempraktikkan apa yang dicontohkan tadi. Dalam hal ini bertahap minimal 3 hari dalam pelatihan. Akan tetapi lihat kadar kesulitan dalam materi yang disampaikan sesuai dengan bidangnya. seperti halnya dalam pelatihan satu jenis roti ada tahapan dalam pelatihan. Calon pekerja ketika praktik pembuatan roti ada 4 tahap yang akan dilakukan. dihari pertama dilatih membuat adonan. Dihari kedua dilatih proses masak, hari ketiga pengemasan, dihari keempat praktik pembuatan dari proses adonan sampai pengemasan.

Semua jenis kegiatan yang ada di RUTAN harus ada pengawasan. Begitu juga dalam hal pelatihan setiap bidang pelatihan dan aktifitas yang ada dibengkel kerja ada pengawasan. Pengawasan dalam pelatihan mencakup acara pelatihan, keseriusan peserta dan materi yang disampaikan.

\section{Evaluasi}

Evaluasi disini dibagi menjadi dua bagian yakni evaluasi peserta dan proses pelatihan keterampilan dan evaluasi bulanan bengkel kerja oleh BIMKEG. Adapun penjelasannya sebagai berikut:

1) Evaluasi peserta pelatihan keterampilan

Di dalam evaluasi hasil pelatihan keterampilan, instruktur dan pengurus BIMKEG menilai hasil pelatihan yang sudah dilaksanakan

Narapidana Di Lapas Perempuan Kelas Iia Semarang" (Diponegoro University, 2019). 
oleh peserta. Adapun hal ini dibutuhkan proses menentukan peserta pelatihan keterampilan yang bersungguh-sungguh dalam pelatihan dengan cara menilai kinerja peserta dan kesungguhan mengikuti pelatihan. Setelah itu pelatih dan pengurus memilih peserta yang memperoleh hasil yang terbaik dalam kerjanya. Yang kerjanya baik maka akan dipekerjakan sebagai tamping di bidangnya. Cara penilaiannya dengan cara mengawasi berjalannya pelatihan keterampilan dan menilai kinerja peserta.

2) Evaluasi bengkel kerja oleh BIMKEG

Evaluasi bengkel kerja dilaksanakan satu bulan sekali dengan mengevaluasi bidang keterampilan, tamping pekerja, alat dan keuangan hasil usaha bengkel kerja. Evaluasi bidang keterampilan membahas mengenai perkembangan dan kendala dalam bidang keterampilan, seperti halnya ada kendala rusaknya alat keterampilan jika tidak bisa dipakai lagi maka diganti dengan alat yang baru ataupun bekas. Dalam evaluasi keuangan menjelaskan penghasilan bulanan usaha bengkel kerja dan juga kas masuk dan kas keluar. Evaluasi di bukukan dalam bentuk laporan bulanan dan akan di bahas bersama setiap akhir bulan dilaporakan dalam rapat bulanan semua pengurus organisasi dalam struktural Rumah tahanan.

Dari keseluruhan aspek manajemen pelatihan kerja bagi warga binaan Lembaga pemasyarakatan (LAPAS) setidaknya telah memenuhi 5 (lima) fungsi manajemen ${ }^{26}$. Kelima fungsi tersebut adalah perencanaan berkaitan dengan berkaitan dengan penyusunan tujuan dan rangkaian kegiatan untuk mencapai tujuan lembaga penyelenggara pendidikan luar sekolah.

26 D. Sudajana. 2000. Manajemen Program Pendidikan Untuk Pendidikan Luar Sekolah, Falah Production, Bandung. Hlm: 11
Selanjutnya pengorganisasian yang merupakan kegiatan mengidentifikasi dan memadukan sumber-sumber yang diperlukan kedalam kegiatan yang akan dilakukan dalam mencapai tujuan yang telah ditetapkan. Sumber-sumber itu meliputi tenaga manusia, fasilitas, alat-alat dan biaya yang tersedia atau dapat disediakan. Dengan kata lain dapat dikemukakan bahwa pengorganisasian adalah upaya melibatkan semua sumber manusia kedalam kegiatan yang terpadu untuk mencapai tujuan lembaga atau organisasi penyelenggara pendidikan luar sekolah. ${ }^{27}$

Ketiga adalah penggerakan yang memainkan peranan yang sangat penting, di samping itu penggerakan berperanan pula dalam fungsi manajemen lainnya seperti pembinaan, penilaian dan pengembangan. Fungsi penggerakan ialah untuk mewujudkan tingkat penampilan dan partisipasi yang tinggi dari setiap pelaksana yang terlibat dalam kegiatan untuk mencapai tujuan yang ditetapkan.

Keempat adalah pengawasan, hal ini merupakan fungsi manajemen lainnya adalah pembinaan. Didalamnya termasuk pengawasan, supervisi, dan monitoring. Pembinaan diselenggarakan melalui pendekatan langsung dan tidak langsung. Pendekatan langsung dilakukan oleh pengelola dilakukan terhadap para penyelenggara dan pelaksana program atau kegiatan pendidikan luar sekolah. Pendekatan tidak langsung dilakukan melaui staf atau pihak lain berkaitan dengan tugas para penyelenggara dan pelaksana.

Kelima Penilaian, berkaitan dengan kegiatan pengumpulan, pengolahan dan penyajian informasi untuk dijadikan masukan dalam pengambilan keputusan. Sasaran penilaian atau evaluasi dapat meliputi: (1) Keseluruhan fungsi manajemen, sejak perencana sampai pengembangan (2) Seluruh komponen proses hasil, dan pengaruh suatu program pendidikan luar sekolah.

Penilaian dilakukan secara berkelanjutan dan diarahkan untuk mengetahui tingkat pencapaian tujuan yang

27 Ridhowati, "Manajemen Pembinaan Mental Spiritual Terhadap Narapidana Pada Lembaga Permasyarakatan Way Huwi Kabupaten Lampung Selatan.” 
telah ditetapkan, proses kegiatan dalam pencapaian tujuan, dan penyimpangan kegiatan dari rencana yang telah disusun. Mengacu pada teori Siagian tersebut, dalam manajemen pelatihan bagi narapidana di RUTAN sudah sesuai dengan teori Siagian, walaupun tidak sama persis secara keseluruhan dengan teorinya Siagian. Langkah awal dalam manajemen pelatihan keterampilan adalah melakukan perencanaan, perencanaan dalam teori Pont sudah dilakukan oleh pihak BIMKEG dalam hal pelatihan. Hal ini dalam tabel diatas dibuktikan dengan adanya penyusunan tujuan pelatihan keterampilan bagi narapidana adalah menambah pengalaman tentang dunia kerja jika, menambah ilmu melalui pelatihan bengkel kerja, merubah karakter narapidana dan membangun kemandirian narapidana paska narapidana. Adapun bentuk pelatihan tersebut ada delapan yakni pelatihan pembuatan roti, perkayuan, loundri, cuci motor, perternakan, potong rambut, menjahit dan pertanian dan elektro.

Untuk langkah kedua dalam teori Siagian adalah pengorganisasian, dalam pengorganisasian disini sudah SDM pelatih, pembiayaan pelatihan dan alat bantu pelatihan. Seperti dalam hal pelatihan instruktur pelatihan SDM nya dari dalam atau pihak luar, dalam hal alat bantu pelatihan sudah ada dan terfasilitasi. Terkecuali jika alatnya belum ada akan diadakan alat penunjang pelatihan. Dalam hal ini telah dibuktikan adanya pelatihan perkayuan kerjasama dengan DISNAKER dan pelatihan pembuatan roti bekerjasama dengan PT. Mitra AMA beserta bantuan alat produksi roti pada Lapas ${ }^{28}$.

Selanjutnya adalah penggerakan, adapun penggerakan menurut teori Siagian disini pembinaan, penilaian dan pengembangan. Jika dianalisa dalam pelatihan disini mengandung unsur pembinaan dan pengembangan. BIMKEG, peserta dan pelatih berpartisipasi mengikuti pelatihan tersebut.

Ke empat dalam teori Siagian adalah pengawasan, teori Siagian menjelaskan bahwa pengawasan itu adalah pembinaan diselenggarakan melalui pendekatan langsung dan tidak langsung. Dalam

28 Afrilya and Widyarini, "Efektivitas Intervensi Pelatihan Goal Setting Pada Warga Binaan pelatihan ini sudah dilaksanakan dalam hal pendekatan melalui pembinaan pelatihan. Dan setiap aktifitas yang ada dibengkel kerja harus diawasi. Pengawasan dilakukan dengan keikut sertaan pengurus BIMKEG dalam pelatihan tersebut.

Yang terakhir adalah penilaian, penilaian disini disamakan dengan evaluasi. Karena dalam teori Siagian menjelaskan isi penilaian yakni menjelaskan fungsi manajemen dari perencanaan sampai pengolahan dan penyajian informasi untuk dijadikan masukan dalam pengambilan keputusan. Evaluasi deisini ada dua macam evaluasi yakni evaluasi hasil pelatihan dan evaluasi bengkel kerja Di dalam evaluasi hasil pelatihan keterampilan, instruktur dan pengurus BIMKEG menilai hasil pelatihan yang sudah dilaksanakan oleh peserta. Menentukan peserta pelatihan keterampilan yang bersungguh-sungguh dalam pelatihan dengan cara menilai kinerja peserta dan kesungguhan mengikuti pelatihan. Setelah itu pelatih dan pengurus memilih peserta yang memperoleh hasil yang terbaik dalam kerjanya. Yang kerjanya baik maka akan dipekerjakan sebagai tamping di bidangnya. Cara penilaiannya dengan cara mengawasi berjalannya pelatihan keterampilan dan menilai kinerja peserta. Evaluasi selanjutnya adalah evaluasi bengkel kerja dilaksanakan satu bulan sekali dengan mengevaluasi bidang keterampilan, tamping pekerja, alat dan keuangan hasil usaha bengkel kerja. Evaluasi bidang keterampilan membahas mengenai perkembangan dan kendala dalam bidang keterampilan, seperti halnya ada kendala rusaknya alat keterampilan jika tidak bisa dipakai lagi maka diganti dengan alat yang baru ataupun bekas. Dalam evaluasi keuangan menjelaskan penghasilan bulanan usaha bengkel kerja dan juga kas masuk dan kas keluar.

C. Pelaksanaan Pelatihan Kerja Dan Keterampilan Bagi Warga Binaan Pemasyarakatan Sebagai Bentuk Pemenuhan Hak Asasi Manusia

Pembinaan bagi warga binaan pemasyarakatan dilakukan berdasarkan

Sosial (Wbs) Di Panti Sosial Bina Karya (Psbk) Pangudi Luhur Bekasi.” 
sistem pembinaan pemasyarakatan yang dilaksanakan berdasarkan: ${ }^{29}$

a. Pengayoman

Pengayoman adalah perlakuan terhadap Warga Binaan Pemasyarakatan dalam rangka melindungi masyarakat dari kemungkinan diulanginya tindak pidana oleh Warga Binaan Pemasyarakatan, juga memberikan bekal hidupnya kepada Warga Binaan Pemasyarakatan agar menjadi warga yang berguna di dalam masyarakat.

b. Persamaan perlakuan dan pelayanan Persamaan perlakuan dan pelayanan adalah pemberian perlakuan dan pelayanan yang sama kepada Warga Binaan Pemasyarakatan tanpa membeda -bedakan orang.

c. Pendidikan

Pendidikan adalah bahwa penyelenggaraan pendidikan dan bimbingan dilaksanakan berdasarkan pancasila, antara lain penanaman jiwa kekeluargaan, keterampilan, pendidikan kerohanian, dan kesempatan untuk menunaikan ibadah.

d. Pembimbingan

Pembimbingan adalah bahwa penyelengaraan bimbingan dilaksanakan berdasarkan pancasila, antara lain penanaman jiwa kekeluargaan, keterampilan, pendidikan kerohanian dan kesempatan untuk menunaikan ibadah.

e. Penghormatan harkat dan martabat manusia

Penghormatan harkat dan martabat manusia adalah bahwa sebagai orang yang tersesat Warga Binaan Pemasyarakatan harus tetap diperlukan sebagai manusia.

f. Kehilangan kemerdekaan merupakan satu-satunya penderitaan Kehilangan kemerdekaan merupakan satu- satunya penderitaan adalah Warga Binaan Pemasyarakatan harus berada dalam Lapas untuk jangka waktu tertentu, sehingga mempunyai kesempatan penuh untuk memperbaikinya. Selama di Lapas Warga Binaan Pemasyarakatan tetap

29 UU Nomor 12 Tahun 1995 Tentang

Pemasyarakatan. memperoleh hak-haknya yang lain seperti layaknya manusia, dengan kata lain hak perdatanya tetap dilindungi seperti hak memperoleh perawatan kesehatan, makan, minum, pakaian, tempat tidur, latihan, keterampilan, olah raga, atau rekreasi.

g. Terjaminnya hak untuk tetap berhubungan dengan keluarga dan orang-orang tertentu.

Terjaminnya hak untuk tetap berhubungan dengan keluarga dan orang-orang tertentu adalah bahwa walaupun Warga Binaan Pemasyarakatan berada di Lapas, tetapi harus tetap didekatkan dan dikenalkan dengan masyarakat dan tidak boleh diasingkan dari masyarakat, antara lain berhubungan dengan masyarakat dalam bentuk kunjungan, hiburan ke dalam Lapas dari anggota masyarakat yang bebas, dan kesempatan berkumpul bersama sahabat dan keluarga seperti program cuti mengunjungi keluarga.

Dalam mengimplementasikan azas tersebut diatas dan dalam upaya mewujudkan pembangunan sumber daya manusia untuk narapidana yang terampil dan berbudaya, yaitu membentuk warga binaan pemasyarakatan (narapidana) agar menjadi manusia seutuhnya, menyadari kesalahannya, memperbaiki diri, tidak mengulangi tindak pidana, dapat berperan dalam pembangunan, dapat hidup secara wajar sebagai warga yang baik dan bertanggung jawab sehingga dapat diterima kembali oleh lingkungan masyarakat, maka setiap narapidana harus menjalani pembinaan selama menjalani masa pidananya. Warga binaan pemasyarakatan perlu mengembangkan kecakapan hidup (life skills) pada Warga Binaan melalui bimbingan kerja selama periode hukuman dalam lembaga pemasyarakatan. Pengembangan kecakapan hidup (life skills) dilaksanakan dengan maksud agar narapidana memiliki bekal keterampilan yang cukup, sehingga setelah bebas diharapkan mampu bersaing dalam bursa tenaga kerja dan/atau dapat hidup mandiri sehingga dapat berguna bagi diri sendiri, keluarga, masyarakat, bangsa dan negara. ${ }^{30}$

30 Khuswatun, "IMPLEMENTASI PROGRAM BIMBINGAN KERJA DALAM PEMBERDAYAAN NARAPIDANA DI 
Karena warga binaan pemasyarakatan yang sedang menjalani hukuman didalam lembaga pemasayarakatan hanya kemerdekaan nya saja yang atas dasar hukum dirampas untuk waktu tertentu tetapi hak-haknya asasinya sebagai manusia tetap harus mendapatkan jaminan dari negera untuk terpenuhi hak-haknya sebagai manusia. ${ }^{31}$ Karena Hak Asasi Manusia (HAM) adalah hak-hak dasar yang dimiliki setiap pribadi manusia yang tanpa hak itu kita mustahil hidup sebagai manusia. Dalam hukum hak asasi manusia, setiap orang berhak untuk mendapatkan penghormatan, perlindungan dan pemenuhan hak asasi manusia dari negara yang dilakukan tanpa diskriminasi.

Berkaitan dengan fungsi lembaga pemasyarakatan maka upaya pemenuhan hak-hak asasi warga binaan pemasyarakatan yang wajib dipenuhi diantaranya adalah hak untuk hidup, hak untuk mengembangkan diri dan hak atas kesejahteraan, agar warga binaan pemasyarakatan dapat melanjutkan hidup dan membangun hidupnya kembali untuk memperoleh hidup yang sejahtera dan hidup berdampingan dengan masyarakat lainnya. ${ }^{32}$

Untuk itu, Lembaga Pemasyarakatan sebagai tempat pembinaan melakukan beberapa kegiatan pendidikan keterampilan kerja yang dikembangkan seperti mendorong kegiatan produksi di beberapa lapas, pameran hasil karya narapidana, dan memantapkan kerjasama dengan instansi terkait dalam mengembangkan kegiatan kerja narapidana.

Merujuk pada data Direktorat Jenderal Pemasyarakatan, dapat dikemukakan beberapa lapas yang telah mampu mendorong produktifitas kegiatan kerja narapidana. Meskipun kapasitas produksi, keterlibatan narapidana, keberlangsungan kegiatan, dan pemasaran produk tersebut masih harus terus ditingkatkan. Beberapa lapas yang mampu mendorong produktifitas yang cukup baik dapat dikemukakan ${ }^{33}$, antara lain:

\section{LAPAS PEREMPUAN KELAS IIA} SEMARANG."

31 Hilman Nur, "Penghapusan Remisi Bagi Koruptor Dalam Perspektif Undang-Undang Nomor 12 Tahun 1995 Tentang Pemasyarakatan," Jurnal Hukum Mimbar Justitia 1, no. 2 (2017): 550.
1. Lapas Binjai; produk yang dihasilkan adalah batako dengan jumlah PNBP yang disetorkan mencapai Rp. 24.000.000 pertahun.

2. Lapas Sukamiskin; kegiatan utamanya adalah di bidang percetakan dengan kapasitas produksi 20.000 pcs.

3. Lapas Karawang; merupakan lapas yang mampu memproduksi beras dengan kapasitas produksinya 2 Ton setiap panen.

4. Lapas Semarang; sudah mengembangkan produksi sepatu yang merupakan hasil kerjasama dengan CV. Sinar Terang Sentosa dan telah menghasilkan produk sebanyak 1.000 pasang.

5. Lapas Madiun; mampu menghasilkan produk berupa mebelair sebanyak 11.424 buah dan paving block sebanyak 4.200 buah yang merupakan kegiatan kerja yang dikerjakan secara mandiri.

6. Lapas Porong Surabaya; menghasilkan produk mebelair sebanyak 1.200 set, sandaran kursi sebanyak 931 set, batu alam sebanyak $7.325 \mathrm{~kg}$, dan membuka jasa laundry yang sudah melayani konsumen sebanyak 1.214 potong. Kegiatan ini mampu menyerap tenaga kerja narapidana sebanyak 110 orang.

7. Lapas Watampone; memfokuskan kegiatan kerja narapidana di bidang pembuatan batu merah. Hingga tahun 2013 ini telah mampu memproduksi batu merah sebanyak 20.000 buah.

8. Rutan Selong; melakukan kegiatan kerja di bidang pembuatan paving block yang mampu menghasilkan 4.909 buah dan pembuatan batako sebesar 7.005 buah.

Berdasarkan data-data dan penjabaran diatas menunjukkan bahwa jaminan terhadap hak asasi manusia wajib dilakukan saklipun terhadap warga binaan pemasyarakatan yang hak kemerdekaannya dirampas, karena upaya pemenuhan hak asasi manusia haruslah dilakukan tanpa diskriminasi.

32 Fauziah Rasad, "Remedi Pelanggaran Hak Asasi Manusia Akibat Tindak Pidana Korupsi (Remedies of Human Rights Violations Due To Corruption)," Jurnal HAM 11, no. 2 (2020): 3-8.

33 Aprilianda, Model Pembinaan Anak Berbasis Pendidikan Layak Anak Dalam Sistem Pemasyarakatan. 
Program pendidikan kerja yang dilakukan Lembaga Pemasyarakatan di Indonesia, berdasarkan data diatas dapat disebut berhasil meningkatkan kemampuan dan keahlihan hidup warga binaan bahkan didalam masa pembinaan di lembaga pemasyarakatan warga binaan dapat melakukan produksi. ${ }^{34} \quad$ Konsep pengembangan diri dalam pengelolaan keterampilan bagi warga binaan ini tentu akan memanusiakan manusia yang merupakan konsep yang ada dalam hak asasi manusia sebagaimana makhluk Tuhan yang saling membutuhkan. hal ini merupakan semangat kehidupan manusia Indonesia sebagaimana tercantum dalam nilai-nilai Pancasila. ${ }^{35}$

Untuk itu, program latihan kerja bagi warga binaan untuk mendorong kecakapan hidup bagi warga binaan pemasyarakatan haruslah diberikan jaminan hukum sabagai program wajib bagi warga binaan, sehingga tujuan yang diharapkan dalam sistem pemasyarakatan dapat berhasil. Hal ini menjadi penting karena didalm peraturan perundang-undangan yang ada tidak ada pengaturan tentang kewajiban bagi warga binaan pemasyarakatan untuk mengikuti program bimbingan kerja yang ada di Lembaga Pemasyarakatan. Karena pentingnya, supporting dalam bentuk fasilitas, ruang kerja dan akses pemasaran juga harus disiapkan oleh Pemerintah.

\section{KESIMPULAN}

Berdasarkan data-data dan uraian diatas dapat ditarik kesimpulan bahwa sistem pemasyarakatan diselenggarakan dalam rangka membentuk warga binaan agar menjadi manusia seutuhnya, menyadari kesalahan, memperbaiki diri dan tidak mengulangi tindak pidana sehingga dapat diterima kembali oleh lingkungan masyarakat, dapat aktif berperan dalam pembangunan dan dapat hidup secara wajar sebagai warga Negara yang baik dan bertanggungjawab.

Dari peraturan perundang-undangan yang menjadi jaminan hukum terhadap pembinaan yang dilakukan oleh Lembaga Pemasyarakatan, dapat diketahui bahwa sistem pemasyarakatan yang dijalankan oleh Lembaga Pemasyarakatan berorientasi terhadap pembinaan warga binaan

34 Herien Puspitawati, "Konsep, Teori Dan Analisis Gender," Ekologi Manusia 2 (2013): 1-13. pemasyarakatan agar warga binaan dapat memperbaiki pribadinya sehingga tidak mengulangi lagi tindak pidana yang pernah dilakukannnya dan dapat melanjutkan hidup serta membangun hidupnya kembali untuk memperoleh hidup yang sejahtera dan dapat hidup berdampingan dengan masyarakat lainnya.

Dan karena upaya pemenuhan hak asasi manusia haruslah dilakukan tanpa diskriminasi, maka upaya pemenuhan dan jaminan terhadap hak asasi manusia wajib dilakukan sakalipun terhadap warga binaan pemasyarakatan yang hak kemerdekaannya dirampas. Program pendidikan kerja yang dilakukan Lembaga Pemasyarakatan di Indonesia, adalah bagian dari upaya pemenuhan hak hidup, hak atas pendidikan dan hak atas kesejahteraan warga binaan pemasyarakatan, dan berdasarkan data yang ada upaya pengembangan kecakapan hidup warga binaan pemasyarakatan melalui program bimbingan keterampilan dan kerja yang dilakukan telah berhasil meningkatkan kemampuan dan keahlian hidup warga binaan yang mengikuti program tersebut. Bahkan didalam masa pembinaan di lembaga pemasyarakatan warga binaan dapat melakukan produksi dan mendapatkan penghasilan.

\section{SARAN}

Dalam hal bimbingan kerja bagi para warga binaan di lembaga pemasyarakatan (Lapas) selama ini masih terbatas pada pelatihan yang bersifat hard skill, hal tersebut karena pelatihan kerja lebih mudah diterapkan disamping juga terbatasnya tutor sehingga rasio antara tutor dengan warga binaan sering kali tidak ideal. Perlunya Kerjasama antara lapas dengan Lembaga Pelatihan Kerja baik dibidang hard skill maupun soft skill sehingga warga binaan lapas ini selepas keluar dari lapas dapat bekerja maupun berwirausaha dan dapat berbaur kembali dengan masyarakat.

35 Eko Eddya Supriyanto, Eksistensi Nilai-Nilai Pancasila Dalam Kebijakan Ekonomi Indonesia, 1st ed. (Malang: Literasi Nusantara, 2020). 


\section{UCAPAN TERIMA KASIH}

Penulis mengucapkan terima kasih kepada dosen-dosen pada Program Doktor Universitas Borobudur Jakarta, khususnya promotor Disertasi penulis. Tak lupa juga penulis ucapkan terima kasih kepada istri dan anak-anak tercinta yang telah merelakan waktu penulis untuk menempuh Pendidikan. Juga bagi rekan kerja sejawat di Kementerian Hukum dan HAM.

\section{DAFTAR PUSTAKA}

Afrilya, Z., and N. Widyarini. "Efektivitas Intervensi Pelatihan Goal Setting Pada Warga Binaan Sosial (Wbs) Di Panti Sosial Bina Karya (Psbk) Pangudi Luhur Bekasi." Jurnal Ilmiah Psikologi Gunadarma 8, no. 2 (2015): 178774.

Ahmad Zuhdi. "Perkembangan Metodologi Penelitian Hukum." Jurnal Hukum dan Peradilan, 1, no. 2 (2012): 189-206.

Aprilianda, Nurini dkk. Model Pembinaan Anak Berbasis Pendidikan Layak Anak Dalam Sistem Pemasyarakatan. Laporan Akhir Pengkajian Hukum, 2014.

Bourdieu, Pierre. "The Force of Law : Toward a Sociology of the Juridical Field The Force of Law : Toward a Sociology Of" 38, no. 5 (1987).

Ceswara, Dicky Febrian. "Manusia Dalam Sila Pancasila." Lex Scientia Law Review 2, no. 2 (2018): 227-241.

Khuswatun, Khasanah. "IMPLEMENTASI PROGRAM BIMBINGAN KERJA DALAM PEMBERDAYAAN NARAPIDANA DI LAPAS PEREMPUAN KELAS IIA SEMARANG." Diponegoro University, 2019.

Nugraha, Muhyar. "Pola Pembinaan Narapidana Di Lapas Paledang Bogor Sebagai Pelaksanaan Sistem Pemasyarakatan." Jurnal Yustisi 4, no. 2 (2017): 15-27.

Nur, Hilman. "Penghapusan Remisi Bagi Koruptor Dalam Perspektif UndangUndang Nomor 12 Tahun 1995 Tentang Pemasyarakatan." Jurnal Hukum Mimbar Justitia 1, no. 2 (2017): 550.

Pratama, and Fauzi. "Efektivitas Program Bimbingan Kerja Dalam Mengembangkan Life Skill Warga Binaan Penjara." Keguruan dan Ilmu Pendidikan 2, no. 2 (2018): 126-140.
Puspitawati, Herien. "Konsep, Teori Dan Analisis Gender." Ekologi Manusia 2 (2013): 1-13.

Rasad, Fauziah. "Remedi Pelanggaran Hak Asasi Manusia Akibat Tindak Pidana Korupsi (Remedies of Human Rights Violations Due To Corruption)." Jurnal HAM 11, no. 2 (2020): 3-8.

Ridhowati, Fitria (Universitas Raden Intan/Lampung). "Manajemen Pembinaan Mental Spiritual Terhadap Narapidana Pada Lembaga Permasyarakatan Way Huwi Kabupaten Lampung Selatan," 2018.

Supriyanto, Eko Eddya. Eksistensi Nilai-Nilai Pancasila Dalam Kebijakan Ekonomi Indonesia. 1 st ed. Malang: Literasi Nusantara, 2020.

. "Kontribusi Pendidikan Pesantren Bagi Pendidikan Karakter Di Indonesia." Jurnal Pendidikan NUsantara 1, no. 1 (2020): 13-26.

Zaini, Zulfi Diane. "Implementasi Pendekatan Yuridis Normatif Dan Pendekatan Normatif Sosiologis Dalam Penelitian Ilmu Hukum." Pranata Hukum, 2011.

Keputusan Menteri Kehakiman Republik Indonesia No: M. 02-PK.04.10 Tahun 1990, 1990.

Peraturan Menteri Hukum Dan Hak Asasi Manusia Republik Indonesia Nomor 35 Tahun 2018 Tentang Revitalisasi Penyeleyenggaraan Pemasyarakatan, 2018.

UU Nomor 12 Tahun 1995 Tentang Pemasyarakatan, n.d. www.bphn.go.id. 